\title{
Fully oxygenated water columns over continental shelves before the Great Oxidation Event
}

\author{
Chadlin M. Ostrander ${ }^{1,2,{ }^{*} \text {, Sune G. Nielsen }}{ }^{2,3}$, Jeremy D. Owens ${ }^{4}$, Brian Kendall ${ }^{5}$, Gwyneth \\ W. Gordon ${ }^{1}$, Stephen J. Romaniello' ${ }^{1}$, and Ariel D. Anbar ${ }^{1}$ \\ ${ }^{1}$ School of Earth and Space Exploration, Arizona State University, Tempe, AZ, USA \\ ${ }^{2}$ NIRVANA Laboratories, Woods Hole Oceanographic Institution, Woods Hole, MA, USA \\ ${ }^{3}$ Department of Geology and Geophysics, Woods Hole Oceanographic Institution, Woods Hole, \\ MA, USA \\ ${ }^{4}$ Department of Earth, Ocean, and Atmospheric Science, National High Magnetic Field \\ Laboratory, Florida State University, Tallahassee, FL, USA \\ ${ }^{5}$ Department of Earth and Environmental Sciences, University of Waterloo, Waterloo, Ontario, CA
}

\begin{abstract}
Late Archaean sedimentary rocks contain compelling geochemical evidence for episodic accumulation of dissolved oxygen in the oceans along continental margins before the Great Oxidation Event. However, the extent of this oxygenation remains poorly constrained. Here we present thallium and molybdenum isotope compositions for anoxic organic-rich shales of the 2.5 billion-year-old Mount McRae Shale from Western Australia, which previously yielded geochemical evidence of a transient oxygenation event. During this event, we observe an anticorrelation between thalium and molybdenum isotope data, including two shifts to higher molybdenum and lower thalium isotope compositions. Our data indicate pronounced burial of manganese oxides in sediments elsewhere in the ocean at these times, which requires that water columns above portions of the ocean floor were fully oxygenated: all the way from the air-sea interface to well below the sediment-water interface. Well-oxygenated continental shelves were likely the most important sites of manganese oxide burial and mass-balance modeling results suggest that fully oxygenated water columns were at least a regional-scale feature of early-Earth's oceans 2.5 billion years ago.
\end{abstract}

The extent of dissolved $\mathrm{O}_{2}$ accumulation in Earth's oceans before the Great Oxidation Event remains poorly understood (GOE; 2.4 to $2.3 \mathrm{Ga}^{1}$ ). Multiple lines of geochemical evidence indicate that $\mathrm{O}_{2}$ was produced by cyanobacteria in the surface ocean well before

Users may view, print, copy, and download text and data-mine the content in such documents, for the purposes of academic research, subject always to the full Conditions of use:http://www.nature.com/authors/editorial_policies/license.html\#terms

*correspondence to: cmostran@asu.edu.

Author contributions: C.M.O., S.G.N., J.D.O., B.K., and A.D.A. developed the project idea. C.M.O. processed samples and performed $\mathrm{Tl}$ and Mo isotope analyses with contributions from S.G.N., J.D.O., B.K., G.W.G., and S.J.R.. C.M.O. performed the modeling and wrote the manuscript with contributions from all co-authors.

Competing interests: The authors declare no competing interests.

Data Availability: All data generated during this study are included in the supplementary information. 
accumulating in the atmosphere during and after the $\mathrm{GOE}^{2-8}$. Models indicate that cyanobacteria in the surface ocean were capable of promoting mild accumulation of dissolved $\mathrm{O}_{2}$ (up to $25 \mu \mathrm{M}^{9}$ ) in shallow waters under a predominately anoxic atmosphere, perhaps extending across large areas of the ocean ${ }^{10}$. However, it is difficult to test these models because existing geochemical proxies cannot easily be used to assess the breadth and depth of ocean oxygenation.

A case has been made for widespread oxygenation of shallow waters before the GOE in continental margin environments based on carbon isotopes in bulk rock and kerogen from $2.7 \mathrm{Ga}$ carbonate sedimentary rocks ${ }^{2}$. However, this prior work could not determine whether $\mathrm{O}_{2}$ accumulation was restricted to surface waters or if it extended deeper in the water column, let alone whether oxygenation reached bottom-waters and sediments (i.e., a fully oxygenated water column).

A fully oxygenated water column at 2.6-2.5 Ga was inferred from black shales (upper Nauga Formation, Ghaap Group, South Africa) enriched in Re but not Mo relative to average crustal abundances ${ }^{3}$. This geochemical signature occurs when $\mathrm{O}_{2}$ is present in pore waters at a depth of up to about one centimeter below the sediment-water interface, when $\mathrm{Fe}(\mathrm{III})$ becomes the dominant electron acceptor during organic matter oxidation and sulfide accumulation is low ${ }^{11,12}$ (Figure 1, panel A). However, this evidence was restricted to a single continental margin (Griqualand West Basin) and could not be extrapolated to the wider oceans.

If fully oxygenated water columns on continental margins were a widespread feature of preGOE oceans, then Mn oxide burial in sediments beneath these settings would also have been widespread. In the modern ocean, $\mathrm{O}_{2}$ in marine bottom waters and sediments readily oxidizes dissolved $\mathrm{Mn}(\mathrm{II})$ and $\mathrm{Mn}$ (III) to insoluble $\mathrm{Mn}(\mathrm{IV}$ )-bearing minerals that precipitate out of solution ${ }^{13,14}$. In contrast, Mn oxides do not form under anoxic conditions, nor are they buried in anoxic marine sediments. Even if formed under $\mathrm{O}_{2}$-rich conditions, $\mathrm{Mn}$ oxides undergo reductive dissolution shortly after being exposed to anoxic conditions within the water column or sediments ${ }^{13-15}$. Manganese oxides are highly unstable when $\mathrm{O}_{2}$ is absent because in such conditions they are an efficient electron acceptor ${ }^{16}$. Therefore, appreciable Mn oxide burial today only occurs where water columns are fully oxygenated and $\mathrm{O}_{2}$ persistently penetrates sediment pore waters ${ }^{14}$. In Earth's past, Mn oxides should have also been buried where $\mathrm{O}_{2}$ penetrated deeply into marine sediments. This could have occurred under more oxidizing conditions than those identified by Kendall et al. (2010) in the Nauga Formation shales, where Re abundances are elevated but Mo abundances are negligible. Specifically, Mn oxide burial requires penetration of $\mathrm{O}_{2}$ well beyond one centimeter below the sediment water interface and occurs before Fe(III) becomes the primary electron acceptor during organic carbon oxidation ${ }^{14,16}$ (e.g., Figure 1, Panel B).

Here, we pair $\mathrm{Tl}$ and Mo isotope data from the late Archaean $(\sim 2.5 \mathrm{Ga})$ black shales of the Mt. McRae Shale (Hamersley Basin, Western Australia) to track the extent of marine Mn oxide burial before the GOE. The isotopic cycling of both $\mathrm{Tl}$ and Mo in the ocean is directly linked to global Mn oxide burial fluxes ${ }^{17,18}$. Therefore, their paired application is a powerful way to infer the extent of fully oxygenated water columns at a regional-to-global scale, in 
contrast to other proxies (e.g., Re vs Mo enrichments and ${ }^{11}$ sedimentary Fe speciation ${ }^{19}$ ) that focus only on redox conditions in the local water column.

\section{Pairing $\mathrm{Tl}$ and Mo isotopes to track paleoredox conditions}

The use of $\mathrm{Tl}$ isotopes as a paleoredox proxy is relatively new ${ }^{17,20,21}$, but builds on extensive prior study of $\mathrm{Tl}$ isotope systematics. The $\mathrm{Tl}$ isotope composition of modern seawater [reported in epsilon notation: $\varepsilon^{205} \mathrm{Tl}$, where $\varepsilon^{205} \mathrm{Tl}=\left({ }^{205 / 203} \mathrm{Tl}_{\text {sample }} / 205 / 203 \mathrm{Tl}_{\mathrm{NIST}-997}-1\right) \cdot$ $\left.10^{4}\right]$ is homogenous and lighter than that of bulk continental crust $\left(\varepsilon^{205} \mathrm{Tl}_{\text {seawater }}=-6.0\right.$ $\pm 0.3^{[18,22]}$, compared to $\left.\varepsilon^{205} \mathrm{Tl}_{\text {bulk-crust }}=-2.1 \pm 0.3^{[23]}\right)$. The light $\varepsilon^{205} \mathrm{Tl}$ in modern seawater is a result of preferential removal of isotopically heavy $\mathrm{Tl}$ from seawater by $\mathrm{Mn}$ oxides in well-oxygenated marine sediments ${ }^{24}$. Importantly, the contemporaneous seawater $\varepsilon^{205} \mathrm{Tl}$ signature is captured and preserved in sediments from anoxic and sulfidic (i.e. euxinic) basins ${ }^{18}$. Therefore, $\mathrm{Tl}$ isotope studies of sedimentary rocks deposited under euxinic conditions provide a means to track ancient seawater $\varepsilon^{205} \mathrm{Tl}$ signatures, which should vary in response to changes in Mn oxide burial fluxes. In support of this application, two recent studies used $\mathrm{Tl}$ isotope compositions in Mesozoic shales deposited in locally euxinic conditions to track changes in Mn oxide burial fluxes before, during, and after Oceanic Anoxic Events, documenting episodes of significant marine deoxygenation ${ }^{20,21}$.

Molybdenum isotopes are a more established proxy also shown to be sensitive to marine $\mathrm{Mn}$ oxide burial ${ }^{25}$. The modern seawater Mo isotope composition [reported in delta notation: $\delta^{98} \mathrm{Mo}$, where $\left.\delta^{98} \mathrm{Mo}=\left(\left({ }^{98 / 95} \mathrm{Mo}_{\text {sample }}{ }^{98 / 95} \mathrm{Mo}_{\text {NIST-SRM-3134 }}-1\right) \cdot 10^{3}\right)+0.25 \% o^{[26]}\right]$ is heavier than that of bulk continental crust $\left(\delta^{98} \mathrm{Mo}_{\text {seawater }}=2.34 \pm 0.10 \%{ }^{[26]}\right.$, compared to $\delta^{98} \mathrm{Mo}_{\text {bulk-crust }}=0.47 \pm 0.12 \%{ }^{[27]}$ ). This heavy seawater $\delta^{98}$ Mo composition is due largely to preferential removal of lighter-mass Mo isotopes by adsorption to Mn oxides in welloxygenated marine sediments ${ }^{25}$. Similar to Tl, this heavy seawater $\delta^{98}$ Mo value is captured in strongly euxinic settings where Mo removal from bottom waters is nearly quantitative ${ }^{28}$.

It is advantageous to measure $\mathrm{Tl}$ isotopes in addition to Mo isotopes because Mo isotope interpretation is complicated by alternative fractionation pathways that do not affect $\mathrm{Tl}$ isotopes. For example, processes that occur during continental weathering ${ }^{29}$ and riverine transport ${ }^{30}$ can remove isotopically light Mo (but see reference 31 ), but do not cause measurable $\mathrm{Tl}$ isotope fractionation ${ }^{23}$. Weakly sulfidic marine sediments also incorporate lighter-mass Mo isotopes ${ }^{28}$ but impart no known isotopic effect on $\mathrm{Tl}^{18}$. Iron oxides can remove isotopically light Mo and drive seawater to heavy $\delta^{98}$ Mo values $^{32}$, but are unlikely to fractionate $\mathrm{Tl}$ isotopes because $\mathrm{Fe}$ oxides lack the ability to oxidize $\mathrm{Tl}(\mathrm{I})$ to $\mathrm{Tl}(\mathrm{III})$, which is what drives isotopic fractionation during sorption to Mn oxides ${ }^{24,33}$. This study is the first to pair both proxies in the same sample set.

\section{Anti-correlation of Mo and Tl isotopes in the Mt. McRae Shale}

We focus on the $2.5 \mathrm{Ga}$ Mt. McRae Shale from Western Australia in drill core ABDP9 because black shales from the upper part of this formation host convincing evidence for a widespread oxygenation episode predating the $\mathrm{GOE}^{5,6,34-40}$. These rocks are an ideal archive for tracking fluctuations in seawater $\mathrm{Tl}$ and $\mathrm{Mo}$ isotope compositions at $2.5 \mathrm{Ga}$ 
because they were deposited in locally euxinic conditions ${ }^{37}$ that favor preservation of seawater $\delta^{98} \mathrm{Mo}$ and $\varepsilon^{205} \mathrm{Tl}$ values (Figure 1; see supplement for more information about the Mt. McRae Shale).

Molybdenum isotope signatures much heavier than those in igneous crustal rocks were previously found in the Mt. McRae Shale (and in coeval shales from South Africa ${ }^{41}$ ) but could not be definitively ascribed to Mn oxide burial elsewhere in the ocean ${ }^{38}$. If Mn oxides were being buried at this time, $\varepsilon^{205} \mathrm{Tl}$ should also be fractionated relative to bulk continental crust. An anti-correlation between $\varepsilon^{205} \mathrm{Tl}$ and $\delta^{98} \mathrm{Mo}$ is expected because fractionation incurred during Mn oxide adsorption is in opposing directions for the two isotope systems $^{17,18}$.

We find that $\varepsilon^{205} \mathrm{Tl}$ is systematically lighter during two distinct intervals of the euxinic upper shale (US) member in the Mt. McRae Shale: 153.30-144.36 m (US1) and 134.17$126.15 \mathrm{~m}$ (US3) (average $\varepsilon^{205} \mathrm{Tl}=-2.65$ ) (Figure 2). $\delta^{98} \mathrm{Mo}$ exhibits heavier values in these same intervals (average $\delta^{98} \mathrm{Mo}=1.37 \%$ ), revealing the predicted anti-correlation with $\varepsilon^{205} \mathrm{Tl}$. Compared to these intervals, $\mathrm{Tl}$ and $\mathrm{Mo}$ isotope compositions for $144.26-135.58 \mathrm{~m}$ (US2) are heavier (average $\varepsilon^{205} \mathrm{Tl}=-2.39, p$-value $=0.05$, two-tailed unpaired t-test) and lighter (average $\delta^{98} \mathrm{Mo}=1.23 \%$, $p$-value $<<0.05$ ), respectively. A cross-plot of shale samples with both isotope measurements from the US reveals a statistically significant anticorrelation ( $p$-value $=0.01$ ). In contrast to the euxinic US, isotope compositions are invariant in the non-euxinic lower shale member (170-190 m core depth, see supplement for discussion of this interval, and interpretation of concentration data).

\section{Fully oxygenated regional water columns on continental shelves}

Light $\varepsilon^{205} \mathrm{Tl}$ and heavy $\delta^{98} \mathrm{Mo}$ in US1 and US3 provide strong evidence for the formation and subsequent burial of Mn oxides elsewhere in the ocean at these times. To drive the observed isotopic trends, water columns needed to have been fully oxygenated over portions of the ocean floor. Most likely, Mn oxide burial at $2.5 \mathrm{Ga}$ occurred in shallow oxygenated shelf environments where $\mathrm{O}_{2}$ produced within the surface ocean by cyanobacteria was capable of being continuously transferred to underlying waters and marine sediments (e.g., the environment illustrated in Figure 1).

Alternative local basin controls or processes in the sedimentary environment where the Mt. McRae Shale was deposited cannot explain the observed isotope trends in the upper shale member. In a modern euxinic basin that is not well-connected to the open ocean (i.e., the Black Sea), Tl isotopes in the local water column and underlying sediments are heavier than the open-ocean signature ${ }^{18}$. If the Hamersley Basin was also not well-connected to the openocean, then $\varepsilon^{205} \mathrm{Tl}$ of the Mt. McRae Shale may have been higher than the open-ocean signature. This would require even lighter seawater $\varepsilon^{205} \mathrm{Tl}$ compositions during deposition of US1 and US3, which would then imply an even greater extent of sediment Mn oxide burial elsewhere in the oceans. Furthermore, in modern euxinic settings where Mo is not quantitatively transferred from seawater to sediments, sedimentary $\delta^{98}$ Mo compositions are always lighter than the coeval seawater signature ${ }^{28}$. Hence, if Mo removal from euxinic bottom waters in the Hamersley Basin was not quantitative, then seawater $\delta^{98}$ Mo would be 
even heavier than observed in the Mt. McRae Shale, again implying even more significant sediment Mn oxide burial elsewhere in the ocean.

In theory, the observed $\mathrm{Tl}$ and Mo isotope shifts might be alternatively explained by "shuttling" of $\mathrm{Tl}$ and Mo bound to oxide minerals formed in oxic surface waters to underlying anoxic waters and/or sediments on Late Archaean continental margins, where these elements could then be captured in euxinic sediments. If so, fully oxygenated water columns would not be required to explain the antithetic shifts in $\mathrm{Tl}$ and Mo isotopes recorded in the Mt. McRae Shale. However, this notion is not supported by observations in the modern Cariaco Basin, a modern analog environment where Mn oxides are formed in oxygenated surface waters and subsequently transported to euxinic bottom waters and sediments deeper in the basin ${ }^{42}$. An oxide shuttle should cause $\varepsilon^{205} \mathrm{Tl}$ in euxinic sediments to be heavier than in surface oxic seawater ${ }^{24}$. This is not observed, however. Rather, euxinic sediment $\varepsilon^{205} \mathrm{Tl}$ in the Cariaco Basin is indistinguishable from overlying seawater (average $\varepsilon^{205} \mathrm{Tl}_{\text {euxinic }}=-5.1 \pm 1.3 ; 2 \mathrm{SD}$ vs. $\left.\varepsilon^{205} \mathrm{Tl}_{\text {seawater }}-5.5 \pm 0.7 ; 2 \mathrm{SD}\right)^{18}$. One possible explanation for this lack of $\mathrm{Tl}$ isotope is that $\mathrm{Tl}$ released by $\mathrm{Mn}$ oxide dissolution in sulfidic deep waters is first re-mixed and re-homogenized with the dissolved Tl pool prior to Tl capture in pyrite. Regardless, since anoxic sediments in the modern Cariaco Basin do not preserve the $\mathrm{Tl}$ isotope effects of oxide adsorption ${ }^{18}$ even though oxide minerals are shown to be delivered at least transiently to these sediments ${ }^{42}$, a Mn oxide shuttle in redoxstratified marine basins probably had a minimal impact on the Late Archaean seawater Tl isotope mass-balance.

Although there are proposed pathways of $\mathrm{Mn}$ oxide formation that do not require $\mathrm{O}_{2}$, they would not be likely to cause the observed isotopic effects in the upper shale member. Oxidation of reduced $\mathrm{Mn}$ in the upper water column by hypothesized Mn-oxidizing phototrophs ${ }^{43}$ or by UV light ${ }^{44}$ cannot account for burial at the seafloor because underlying anoxic waters and sediments would recycle Mn back into solution [as Mn(II)] ${ }^{13,14}$. The high abundance of $\mathrm{Fe}(\mathrm{II})$ in deep ferruginous waters of the Archaean oceans ${ }^{1}$, for example, would readily promote reduction of Mn oxides in anoxic waters. If the water column or sediment pore waters were anoxic, even seasonally ${ }^{15}$, reductive dissolution of Mn oxides would release sorbed $\mathrm{Tl}$ and Mo. Additionally, invoking an $\mathrm{O}_{2}$-free explanation to explain the observed isotopic trends requires neglecting the many independent lines of evidence for a "whiff" of $\mathrm{O}_{2}$ at $2.5 \mathrm{Ga}^{5,6,34-40}$.

Paleo-seawater $\varepsilon^{205} \mathrm{Tl}$ and $\delta^{98} \mathrm{Mo}$ can be estimated directly from the Mt. McRae Shale data and used to reconstruct ocean redox conditions. Measured $\varepsilon^{205} \mathrm{Tl}$ values serve as a direct estimate for the coeval seawater signature (as low as $-3.57 \pm 0.48$ ) because euxinic sediments capture the overlying seawater $\mathrm{Tl}$ isotope value ${ }^{18}$. The $\delta^{98}$ Mo recorded in euxinic marine sediments is always equal to or lighter than seawater ${ }^{28}$, and thus represent a lower limit for the coeval seawater signature (as heavy as $1.56 \pm 0.10 \%$ ). It is possible, indeed likely, that the $\mathrm{Tl}$ and Mo isotope compositions of seawater fluctuated during deposition of the US member of the Mt. McRae Shale. Deposition of this interval is estimated to have occurred over $\sim 11$ million years ${ }^{34}$ and the "whiff" of $\mathrm{O}_{2}$ was likely a transient episode of even shorter duration ${ }^{39}$. To estimate ocean redox conditions during peak Mn oxide burial, we use the lightest $\varepsilon^{205} \mathrm{Tl}$ and heaviest $\delta^{98} \mathrm{Mo}$ from the US member. During peak Mn oxide 
burial, retention of heavier-mass $\mathrm{Tl}$ and lighter-mass Mo isotopes would have been maximized, resulting in the lightest $\varepsilon^{205} \mathrm{Tl}$ and heaviest $\delta^{98}$ Mo seawater signatures. Unsurprisingly, the lightest $\varepsilon^{205} \mathrm{Tl}(-3.57 \pm 0.48$ epsilon units at $148.75 \mathrm{~m})$ and heaviest $\delta^{98} \mathrm{Mo}(1.56 \pm 0.10 \%$ at $145.74 \mathrm{~m})$ occur during US1, an interval that hosts multiple lines of

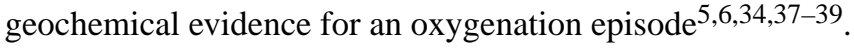

Using the estimated seawater $\varepsilon^{205} \mathrm{Tl}$ and $\delta^{98} \mathrm{Mo}$, ocean redox conditions can be inferred using isotope mass-balance equations as follows:

$\varepsilon^{205} \mathrm{Tl}_{\text {Inputs }}=\varepsilon^{205} \mathrm{Tl}_{\mathrm{AOC}}\left(f_{\mathrm{AOC}}\right)+\varepsilon^{205} \mathrm{Tl}_{\text {oxic }}\left(f_{\mathrm{Tl}-\text { oxic }}\right)+\varepsilon^{205} \mathrm{Tl}$ other $\left(f_{\text {other }}\right)$

and

$\delta^{98} \mathrm{Mo}_{\text {Inputs }}=\delta^{98} \mathrm{Mo}_{\text {euxinic }}\left(f_{\text {euxinic }}\right)+\delta^{98} \operatorname{Mo}_{\mathrm{SAD}}\left(f_{\mathrm{SAD}}\right)+\delta^{98} \mathrm{Mo}_{\text {oxic }}\left(f_{\text {Mo-oxic }}\right)$

where $\varepsilon^{205} \mathrm{Tl}_{\mathrm{X}}$ and $\delta^{98} \mathrm{Mo}_{\mathrm{X}}$ represent the isotopic composition of average oceanic inputs and outputs, and $f_{\mathrm{X}}$ denotes the relative removal flux for each output. For Tl, we designate low-T alteration of oceanic crust $\left(f_{\mathrm{AOC}}\right)$, well-oxygenated Mn oxide-rich sediments ( $\left.f_{\mathrm{Tl}-o x i c}\right)$, and "other" $\left(f_{\text {other }}\right)$ as the three dominant marine outputs. The "other" output signifies Tl removal with no associated isotopic fractionation (e.g., euxinic basins ${ }^{18}$ ). For Mo, similar to recent work, we use euxinic sediments $\left(f_{\text {euxinic }}\right)$, sediments that are sulfidic at depth $\left(f_{\mathrm{SAD}}\right.$; where sulfide is limited to sediment pore waters), and well-oxygenated Mn oxide-rich sediments $\left(f_{\text {Mo-oxic }}\right)$ as the three outputs ${ }^{45}$ (see supplementary material for more detailed information about modeling, including key assumptions).

The mass-balance model results indicate that well-oxygenated Mn oxide-rich sediments were an important sink for both $\mathrm{Tl}\left(f_{\mathrm{Tl}-\mathrm{oxic}}=6-21 \%\right)$ and $\mathrm{Mo}\left(f_{\text {Mo-oxic }}=20-34 \%\right)$ at $2.5 \mathrm{Ga}$. Together, these results suggest that fully oxygenated shelf environments were a common feature on continental margins, at least regionally at $2.5 \mathrm{Ga}$.

We make no attempt here to convert these fluxes into the areal extent of seafloor because the flux per areal unit into these marine outputs was likely much different in the Archean compared to today. Burial rates of $\mathrm{Tl}$ and Mo in modern oxic marine environments that bury Mn oxides are very low, much lower than their burial rates into other modern marine outputs (e.g., burial of $\mathrm{Tl}$ during low-T alteration of oceanic crust ${ }^{46}$ and burial of Mo under strong euxinic conditions ${ }^{45}$ ). For this reason, seafloor area calculations using modern $\mathrm{Tl}$ and Mo burial rates and our ancient seawater isotope signature estimates would require the majority of the seafloor at $2.5 \mathrm{Ga}$ to have been oxic. Expansive oxic conditions before the GOE is unlikely because many independent lines of evidence support a predominately anoxic global ocean at this time ${ }^{1}$. Most likely, burial rates of $\mathrm{Tl}$ and $\mathrm{Mo}$ in $2.5 \mathrm{Ga}$ oxic environments were much higher than today. For example, dissolved Mn concentrations in Archean seawater may have been four orders of magnitude higher than today ${ }^{47}$, providing a strong potential for high $\mathrm{Mn}$ oxide burial rates in oxic environments, and therefore a stronger potential for $\mathrm{Tl}$ and Mo adsorption. Furthermore, the burial rate of Mo (and potentially also of $\mathrm{Tl}$ ) into euxinic environments could have been much lower than today because sulfate concentrations in Archean oceans were very low ${ }^{48}$. Euxinic conditions in a low-sulfate ocean could have been much weaker than today, lowering the potential for sedimentary retention of Mo. In 
summary, a smaller area of 2.5 Ga seafloor burying Mn oxides could conceivably drive a more pronounced seawater $\mathrm{Tl}$ and Mo isotope signature effect than today but is difficult to estimate precisely.

Our findings provide a new perspective on marine oxygenation at $2.5 \mathrm{Ga}$, on the eve of the GOE. Multiple lines of geochemical evidence provide strong support for $\mathrm{O}_{2}$ in shallow waters of the Hamersley Basin at $2.5 \mathrm{Ga}^{5,6,34}$ and the adjoining Griqualand West Basin ${ }^{4,41}$ (which may have bordered the same ocean basin ${ }^{49}$ ). However, because Mn oxide burial requires fully oxygenated water columns at $2.5 \mathrm{Ga}$, our multi-isotope data supports more oxygenated continental shelves over a greater area than previously recognized using other geochemical datasets. Specifically, the inferred seawater $\varepsilon^{205} \mathrm{Tl}$ and $\delta^{98}$ Mo requires fully oxygenated water columns in shelf environments within the Hamersley Basin and adjoining basins(s), and potentially even large portions of the continental margins worldwide. Our results highlight the significant and expanding role of cyanobacteria as engineers of the Archean biosphere, particularly in the runup to the Great Oxidation Event.

\section{Methods: $\mathrm{Tl}$ isotopes}

Tl sample preparation and purification were performed in the NIRVANA Laboratory at Woods Hole Oceanographic Institution (WHOI), as well as in Dr. Jeremy Owens' Laboratory at Florida State University (FSU) within the National High Magnetic Field Laboratory (NHMFL). Powdered samples from ABDP9 were leached using a method from previous literature ${ }^{17,20}$, which has been shown to effectively separate authigenic $\mathrm{Tl}$ (i.e. $\mathrm{Tl}$ bound to pyrite) from detrital Tl. Each fraction was subsequently digested following procedures discussed in that literature. Ion exchange chromatography was completed using previously described techniques ${ }^{51,52}$. Similar to recent work ${ }^{20}$, samples were only subjected to one column pass because $\mathrm{Tl}$ concentrations were high and thus very little sample mass was processed.

Tl isotopic analyses were conducted at the WHOI Plasma Mass Spectrometry Facility and at the NHMFL in Tallahassee. At both locations a Thermo Neptune MC-ICPMS was used with an Aridus II desolvating nebulizer sample introduction system. Measurements were made in low-resolution mode utilizing sample-standard bracketing relative to NIST $997 \mathrm{Tl}$ in epsilon notation. External normalization to NIST SRM $981 \mathrm{~Pb}$ was utilized to monitor instrumental mass bias, similar to previous studies ${ }^{51,52}$. Since a known quantity of NIST SRM $981 \mathrm{~Pb}$ was added to each sample, $\mathrm{Tl}$ concentrations could be calculated during MC-ICPMS analysis using the measured ${ }^{205} \mathrm{Tl} /{ }^{208} \mathrm{~Pb}$ ratios. Tl isotope values are reported in epsilon notation relative to NIST $997 \mathrm{Tl}$ metal. One USGS shale SCO-1 standard was leached, purified, and analyzed with each sample set to monitor accuracy and showed good reproducibility $\left(\varepsilon^{205} \mathrm{Tl}_{\text {authigenic }}=-2.80 \pm 0.13,2 \mathrm{SD}, \mathrm{n}=8\right)$ compared to a recent study: $(-2.92 \pm 0.11)^{(20)}$. 


\section{Mo isotopes}

All Mo sample digestion, isotope purification, and analysis were completed at the W.M.

Keck Foundation Laboratory for Environmental Biogeochemistry at Arizona State

University. Quarter cores were cut from ABDP9, powdered, ashed, digested, and

concentrations were analyzed using the same techniques employed in previous work ${ }^{34}$.

Enough sample was then taken from the same digested stock solutions to provide $125 \mathrm{ng}$ Mo that was spiked with an optimal amount of calibrated synthetic Mo isotope double-spike $\left({ }^{97} \mathrm{Mo}\right.$ and ${ }^{100} \mathrm{Mo}$ ) before purification via ion exchange chromatography, again utilizing methods from previous studies ${ }^{53,54}$. The double spike is used for chromatography and instrumental mass fractionation correction.

Isotope ratio measurements were performed on a Thermo Neptune multi-collector ICPMS (MC-ICPMS) in low-resolution mode with an Elemental Scientific Inc. Apex inlet system and using sample-standard bracketing ${ }^{38,55}$. All measurements were made using the Johnson Matthey Specpure Mo plasma standard (Lot \#802309E; RochMo2) as the bracketing standard, and then re-calculated relative to the new international NIST SRM 3134 standard = $+0.25 \%{ }^{(26)}$. Samples and standards were analyzed at a concentration of $25 \mu \mathrm{g} / \mathrm{g}$ Mo, which yielded about three volts of signal on mass 98 . Samples were analyzed in triplicate (at least), with the average 2 SD sample reproducibility being $0.06 \%$, and the maximum being $0.11 \%$. Over the 12-month period of Mo isotope analysis for this study, USGS rock reference material SDO-1 was simultaneously processed with each batch of samples to monitor accuracy and showed good reproducibility $\left(\delta^{98} \mathrm{Mo}=1.00 \pm 0.09 \%\right.$ 2SD compared to 1.05 $\pm 0.14 \%$ o from a previous study ${ }^{56}$ ), as did various analytical replicates (Table 1). Lastly, for each analytical run, a series of standards with varying spike-sample ratios was measured. All samples were within the validated spike-sample range for accurate and precise $\delta^{98} \mathrm{Mo}$ values.

\section{Supplementary Material}

Refer to Web version on PubMed Central for supplementary material.

\section{Acknowledgments:}

We would like to thank Wang Zheng and Jurek Blusztajn for their help with instrumental analysis at Arizona State University and Woods Hole Oceanographic Institution, respectively. This research was supported financially by the NSF Frontiers in Earth System Dynamics program (award NSF EAR-1338810), the NSF Chemical Oceanography program (award OCE 1434785), the NASA Exobiology program (award number NNX16AJ60G), and a NSERC Discovery Grant (award number RGPIN-435930). This material is based upon work supported by the National Science Foundation Graduate Research Fellowship Program under Grant No. 026257-001. Any opinions, findings, and conclusions or recommendations expressed in this material are those of the authors and do not necessarily reflect the views of the National Science Foundation.

\section{References:}

1. Lyons TW, Reinhard CT \& Planavsky NJ The rise of oxygen in Earth's early ocean and atmosphere. Nature 506, 307-315 (2014). [PubMed: 24553238]

2. Eigenbrode JL \& Freeman KH Late Archean rise of aerobic microbial ecosystems. Proc. Natl. Acad. Sci 103, 15759-15764 (2006). [PubMed: 17043234]

3. Kendall B et al. Pervasive oxygenation along late Archaean ocean margins. Nat. Geosci 3, 647-652 (2010). 
4. Czaja AD et al. Evidence for free oxygen in the Neoarchean ocean based on coupled ironmolybdenum isotope fractionation. Geochim. Cosmochim. Acta 86, 118-137 (2012).

5. Kendall B, Brennecka GA, Weyer S \& Anbar AD Uranium isotope fractionation suggests oxidative uranium mobilization at $2.50 \mathrm{Ga}$. Chem. Geol 362, 105-114 (2013).

6. Stüeken EE, Buick R \& Anbar AD Selenium isotopes support free $\mathrm{O}_{2}$ in the latest Archean. Geology 43, 259-262 (2015).

7. Eickmann B et al. Isotopic evidence for oxygenated Mesoarchaean shallow oceans. Nat. Geosci 11, 133-138 (2018).

8. Koehler MC, Buick R, Kipp MA, Stüeken EE \& Zaloumis J Transient surface ocean oxygenation recorded in the $\sim 2.66-G a$ Jeerinah Formation, Australia. Proc. Natl. Acad. Sci 115, 7711-7716 (2006).

9. Kasting JF Models relating to Proterozoic atmospheric and ocean chemistry In: Schopf J, Klein C (Eds), The Proterozoic Biosphere, A Multidisciplinary Study. Cambridge University Press, 11851187 (1992).

10. Olson SL, Kump LR \& Kasting JF Quantifying the areal extent and dissolved oxygen concentrations of Archean oxygen oases. Chem. Geol 362, 35-43 (2013).

11. Morford JL, Emerson SR, Breckel EJ \& Kim SH Diagenesis of oxyanions (V, U, Re, and Mo) in pore waters and sediments from a continental margin. Geochim. Cosmochim. Acta 69, 5021-5032 (2005)

12. Morford JL, Martin WR \& Carney CM, Rhenium geochemical cycling: Insights from continental margins. Chem. Geol 324-325, 73-86 (2012)

13. Burdige DJ The biogeochemistry of manganese and iron reduction in marine sediments. Earth Sci. Rev 35, 249-284 (1993).

14. Calvert SE \& Pedersen TF Sedimentary Geochemistry of Manganese: Implications for the environment of formation of manganiferous black shales. Econ. Geol 91, 36-47 (1996).

15. Kristensen E Kristiansen KD \& Jensen MH Temporal behavior of Manganese and Iron in a Sandy Coastal Sediment Exposed to Water Column Anoxia. Estuaries 26, 690-699 (2003).

16. Froelich PN et al. Early oxidation of organic matter in pelagic sediments of the eastern equatorial Atlantic: Suboxic diagenesis. Geochim. Cosmochim. Acta 43, 1075-1090 (1979).

17. Nielsen SG et al. Thallium isotopes in early diagenetic pyrite - A paleoredox proxy? Geochim. Cosmochim. Acta 75, 6690-6704 (2011).

18. Owens JD, Nielsen SG, Horner TJ, Ostrander CM \& Peterson LC Thallium-isotopic compositions of euxinic sediments as a proxy for global manganese-oxide burial. Geochim. Cosmochim. Acta 213, 291-307 (2017).

19. Raiswell $\mathrm{R}$ et al. The iron paleoredox proxies: a guide to pitfalls, problems and proper practice. Am. J. Sci 318, 491-526 (2018).

20. Ostrander CM, Owens JD \& Nielsen SG Constraining the rate of oceanic deoxygenation leading up to a Cretaceous Oceanic Anoxic Event (OAE-2: 94Ma). Sci. Adv 3, e1701020 (2017). [PubMed: 28808684]

21. Them TR et al. Thallium isotopes reveal protracted anoxia during the Toarcian (Early Jurassic) associated with volcanism, carbon burial, and mass extinction. Proc. Natl. Acad. Sci doi:10.1073/ pnas.1803478115 (2018).

22. Nielsen SG et al. Hydrothermal fluid fluxes calculated from the isotopic mass balance of thallium in the ocean crust. Earth and Planet. Sci. Lett 251, 120-133 (2006).

23. Nielsen SG et al. Thallium isotopic composition of the upper continental crust and rivers - an investigation of the continental sources of dissolved marine thallium. Geochim. Cosmochim. Acta 19, 2007-2019 (2005).

24. Nielsen SG et al. Towards an understanding of thallium isotope fractionation during adsorption to manganese oxides. Geochim. Cosmochim. Acta 117, 252-265 (2013).

25. Wasylenki LE et al. The molecular mechanism of Mo isotope fractionation during adsorption to birnessite. Geochim. Cosmochim. Acta 75, 5019-5031 (2011).

26. Nägler TF et al. Proposal for an international molybdenum isotope measurement standard and data representation. Geostand. Geoanal. Res doi: 10.1111/j.1751-908X.2013.00275.x (2014). 
27. Willbold M \& Elliot T Molybdenum isotope variations in magmatic rocks. Chem. Geol 449, $253-$ 268 (2017).

28. Neubert N, Nägler TF \& Böttcher ME Sulfidity controls molybdenum isotope fractionation into euxinic sediments: Evidence from the modern Black Sea. Geology 36, 775-778 (2008).

29. Siebert $\mathrm{C}$ et al. Molybdenum isotope fractionation in soils: influence of redox conditions, organic matter, and atmospheric inputs. Geochim. Cosmochim. Acta 162, 1-24 (2015).

30. Archer $\mathrm{C} \&$ Vance D The isotopic signature of the global riverine molybdenum flux and anoxia in the ancient oceans. Nat. Geosci 1, 597-600 (2008).

31. King EK \& Pett-Ridge JC Reassessing the dissolved molybdenum isotopic composition of ocean inputs: The effect of chemical weathering and groundwater. Geology, 10.1130/G45124.1 (2018).

32. Goldberg T, Archer C, Vance D \& Poulton SW Mo isotope fractionation during adsorption to Fe (oxyhydr)oxides. Geochim. Cosmochim. Acta 73, 6502-6516 (2009).

33. Peacock CL \& Moon EM Oxidative scavenging of thallium by birnessite: Explanation for thallium enrichment and stable isotope fractionation in marine ferromanganese precipitates. Geochim. Cosmochim. Acta 84, 297-313 (2012).

34. Anbar AD et al. A whiff of oxygen before the great oxidation event? Science 317, 1903-1906 (2007). [PubMed: 17901330]

35. Kaufman AJ et al. Late Archean biospheric oxygenation and atmospheric evolution. Science 317 , 1900-1903 (2007). [PubMed: 17901329]

36. Garvin J, Buick R, Anbar AD, Arnold GL \& Kaufman AJ Isotopic evidence for an aerobic nitrogen cycle in the latest Archean. Science 323, 1045-1048 (2009). [PubMed: 19229033]

37. Reinhard CT, Raiswell R, Scott C, Anbar AD \& Lyons TW A late Archean sulfidic sea stimulated by early oxidative weathering of the continents. Science 326, 713-716 (2009). [PubMed: 19900929]

38. Duan $\mathrm{Y}$ et al. Molybdenum isotope evidence for mild environmental oxygenation before the Great Oxidation Event. Geochim. Cosmochim. Acta 74, 6655-6668 (2010).

39. Kendall B, Creaser RA, Reinhard CT, Lyons TW \& Anbar AD Transient episodes of mild environmental oxygenation and oxidative continental weathering during the late Archean. Sci. Adv 1:e1500777 (2015). [PubMed: 26702438]

40. Gregory DD et al. The chemical conditions of the late Archean Hamersley basin inferred from whole rock and pyrite geochemistry with $\Delta^{33} S$ and $\delta^{34} S$ isotope analyses. Geochim. Cosmochim. Acta 149, 223-250 (2015).

41. Wille $\mathrm{M}$ et al. Evidence for a gradual rise of oxygen between 2.6 and $2.5 \mathrm{Ga}$ from Mo isotopes and Re-PGE signatures in shales. Geochim. Cosmochim. Acta 71, 2417-2435 (2007).

42. Algeo TJ and Tribovillard N Environmental analysis of paleoceanographic systems based on molybdenum-uranium covariation. Chem. Geol 268, 211-225 (2009).

43. Johnson JE et al. Manganese-oxidizing photosynthesis before the rise of cyanobacteria. Proc. Natl. Acad. Sci 110, 11238-11243 (2013). [PubMed: 23798417]

44. Anbar AD \& Holland HD The photochemistry of manganese and the origin of banded iron formations. Geochim. Cosmochim. Acta 56, 2595-2603 (1992). [PubMed: 11537803]

45. Kendall B, Dahl TW \& Anbar AD Good golly, why Moly? The stable isotope geochemistry of molybdenum. Rev. Mineral. Geochem 82, 682-732 (2017).

46. Nielsen SG, Rehkämper M \& Prytulak J Investigation and application of thallium isotope fractionation. Rev. Mineral. Geochem 82, 759-798 (2017).

47. Holland HD The chemical evolution of the atmosphere and oceans (Princeton Univ. Press, Princeton, NJ, 1984).

48. Habicht KS, Gade M, Thamdrup B, Berg P \& Canfield DE Calibration of sulfate levels in the Archean ocean. Science 298, 2372-2374 (2002). [PubMed: 12493910]

49. De Kock MO, Evans DAD \& Beukes NJ Validating the existence of Vaalbara in the Neoarchean. Precambr. Res 174, 145-154 (2009).

50. Madison AS, Tebo BM, Mucci A, Sundby B \& Luther GW, III Abundant porewater Mn(III) is a major component of the sedimentary redox system. Science 341, 875-878 (2013). [PubMed: 23970696] 


\section{References cited only in Methods:}

51. Rehkämper M \& Halliday AN The precise measurement of Tl isotopic compositions by MCICPMS: Applications to the analysis of geological materials and meteorites. Geochim. Cosmochim. Acta 63, 935-944 (1999).

52. Nielsen SG, Rehkämper M, Baker JA \& Halliday AN The precise and accurate determination of thallium isotope compositions and concentrations for water samples by MC-ICPMS. Chem. Geol 204, 109-124 (2004).

53. Siebert C, Nägler TF \& Kramers JD Determination of the molybdenum isotope fractionation by double-spike multicollector inductively coupled plasma mass spectrometry. Geochem. Geophys. Geosyst 2:2000GC000124 (2001).

54. Barling J, Arnold GL \& Anbar AD Natural mass-dependent variations in the isotopic composition of molybdenum. Earth and Planet. Sci. Lett 193, 447-457 (2001).

55. Kendall B, Creaser RA, Gordon GW \& Anbar AD Re-Os and Mo isotope systematics of black shales from the Middle Proterozoic Velkerri and Wollogorang Formations, McArthur Basin, northern Australia. Geochim. Cosmochim. Acta 73, 2534-2558 (2009).

56. Goldberg $\mathrm{T}$ et al. Resolution of inter-laboratory discrepancies in Mo isotope data: an intercalibration. J. Anal. At. Spectrom 28, 724-735 (2013). 


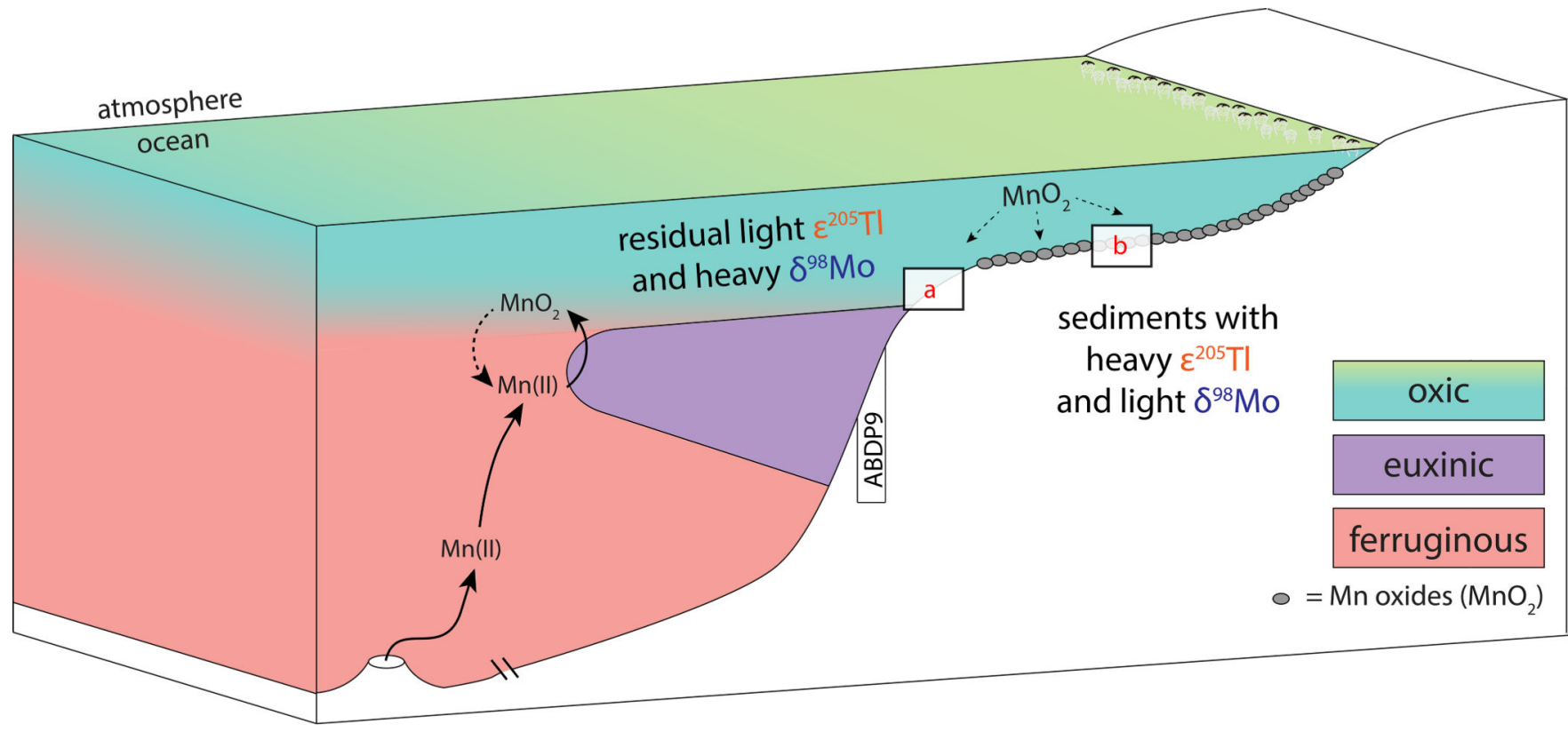

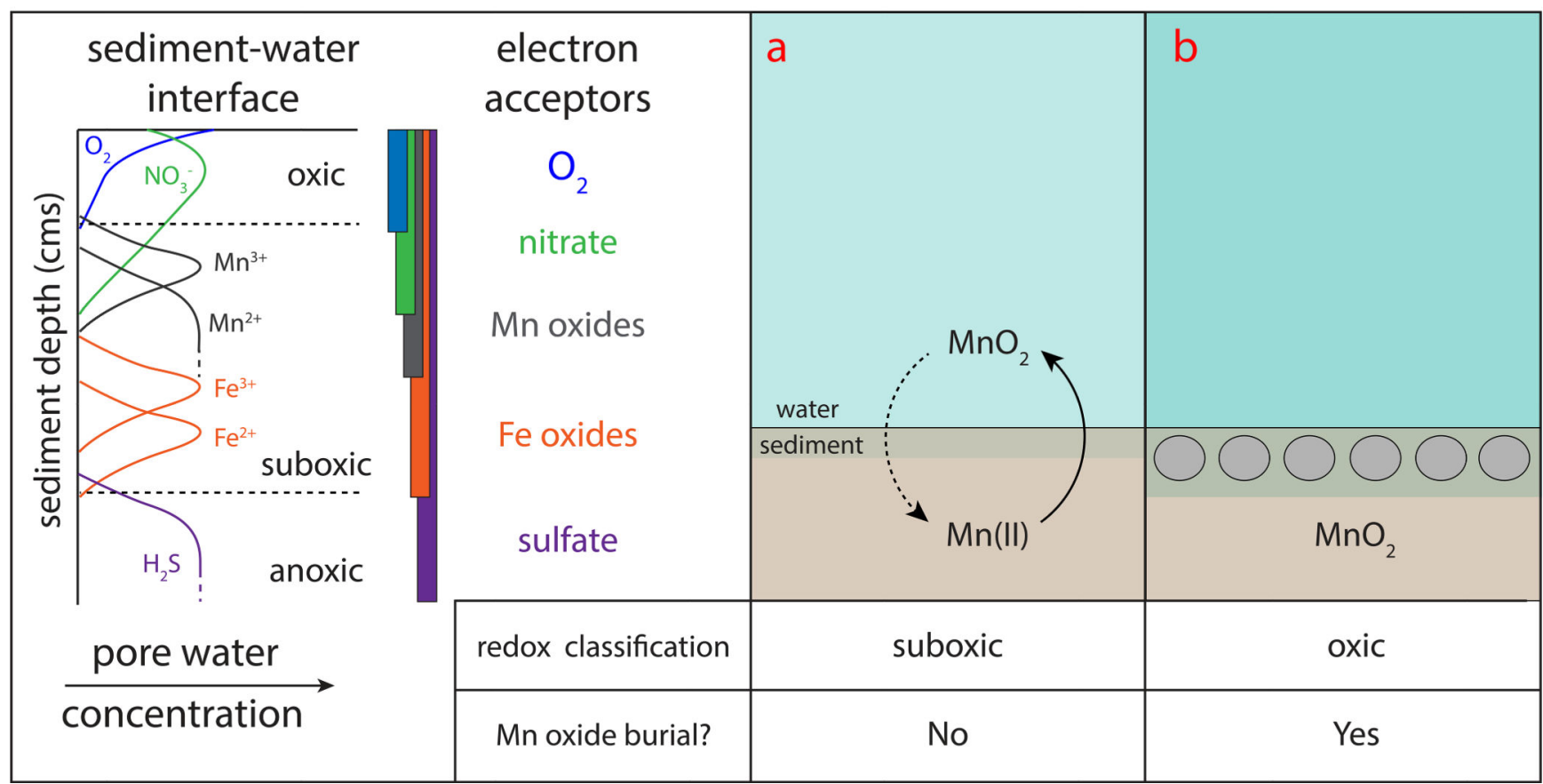

Figure 1. Illustration of a possible well-oxygenated marine margin before the GOE.

Evidence exists for sufficient $\mathrm{O}_{2}$ accumulation in an ancient water column between 2.6 and $2.5 \mathrm{Ga}$ to weakly oxygenate underlying sediments ${ }^{3}$ ("suboxic"; Panel A). However, $\mathrm{O}_{2}$ penetration into these sediments was not sufficient to promote Mn oxide burial ${ }^{11,12}$. If settings capable of burying Mn oxides were present in ancient oceans ("oxic"; Panel B) over a large seafloor area, then seawater $\mathrm{Tl}$ and Mo isotope compositions would have decreased and increased, respectively. The Mt. McRae Shale was deposited under locally euxinic conditions ${ }^{37}$ and should therefore have captured these changes in seawater isotope signatures ${ }^{18,28}$. Sedimentary redox structure is modified from previous work ${ }^{50}$. 


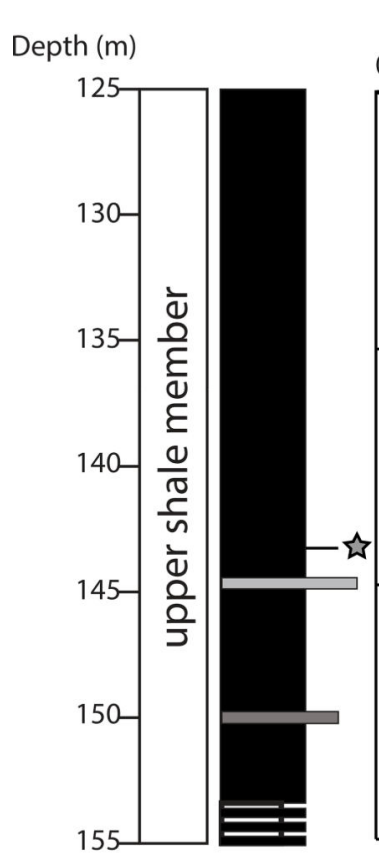

$$
\mathrm{Fe}_{\mathrm{HR}} / \mathrm{Fe}_{\mathrm{T}}
$$
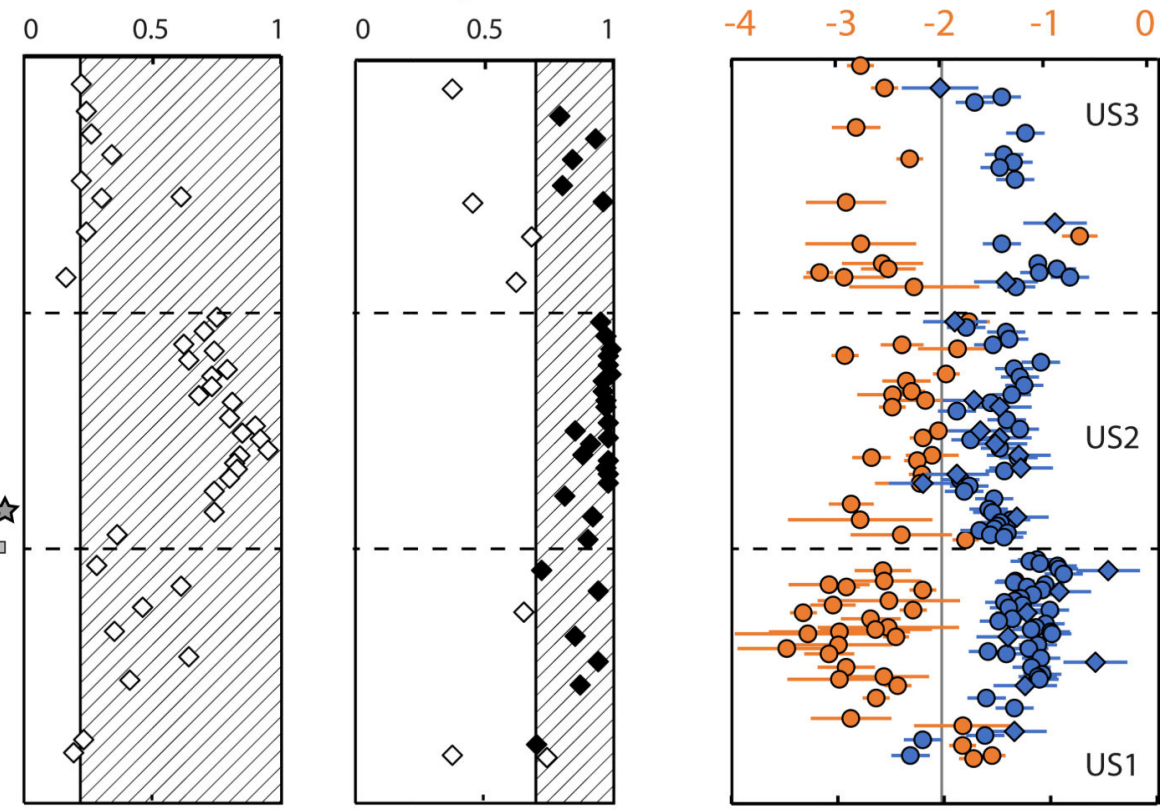
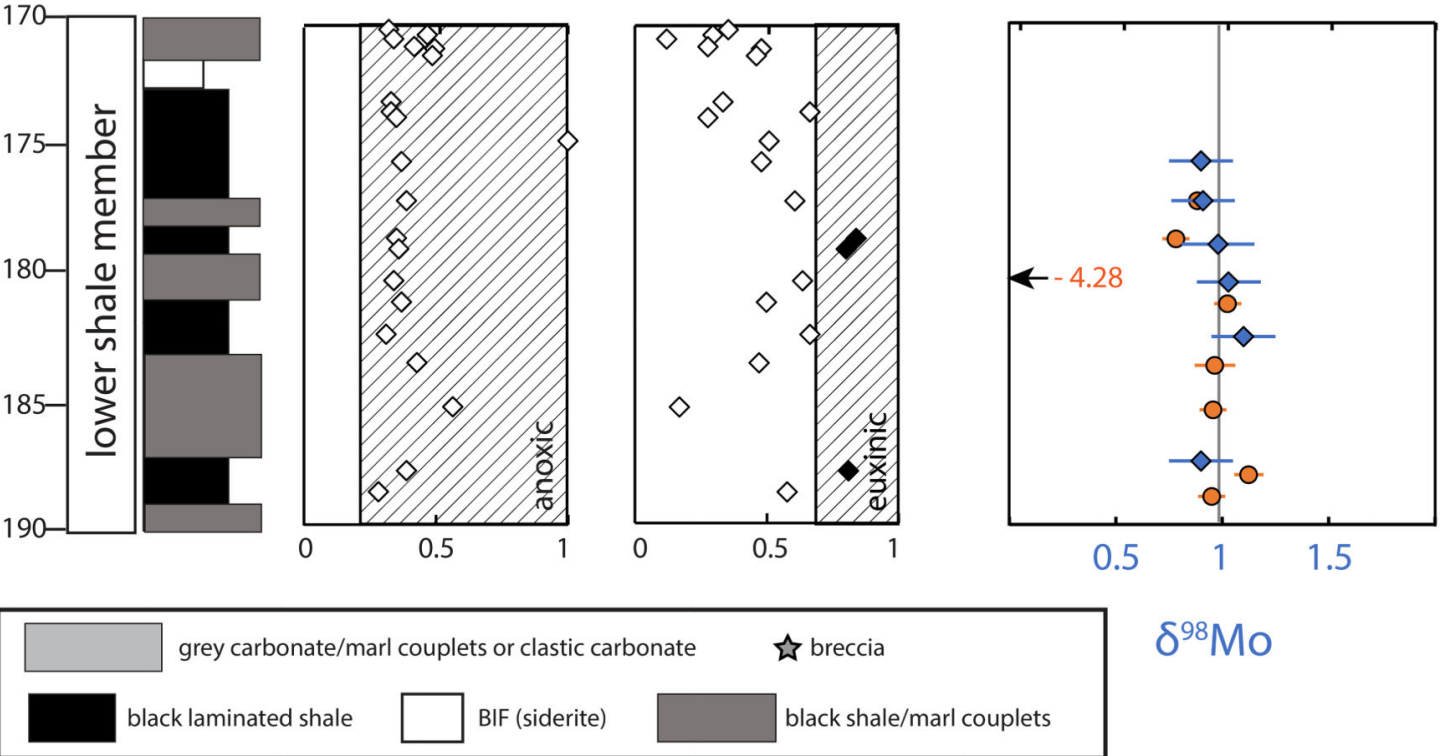

$\delta^{98} \mathrm{Mo}$

Figure 2. Geochemical profiles in organic-rich shales from the Mt. McRae Shale (orange = $\varepsilon^{205} \mathrm{Tl}$, blue $\left.=\delta^{98} \mathrm{Mo}\right)$.

Hatched boxes represent values indicative of anoxic $\left(\mathrm{Fe}_{\mathrm{HR}} / \mathrm{Fe}_{\mathrm{T}}>0.22\right)$ and euxinic $\left(\mathrm{Fe}_{\mathrm{Py}} /\right.$ $\left.\mathrm{Fe}_{\mathrm{HR}}>0.7\right)$ deposition ${ }^{19}$. Data that exceed both criteria are in black. Diamonds reflect data from previous work ${ }^{37,38}$ and circles are data from this study. The grey vertical line in the isotope plot represents average isotope compositions from the lower shale member, with the exception of one anomalous $\mathrm{Tl}$ isotope value $\left(\varepsilon^{205} \mathrm{Tl}=-4.28 \pm 0.13\right.$ at $\left.180.33 \mathrm{~m}\right)$. All error bars represent the $2 \mathrm{SD}$ reproducibility of that sample or the external long-term reproducibility of natural reference materials, whichever is greater. 


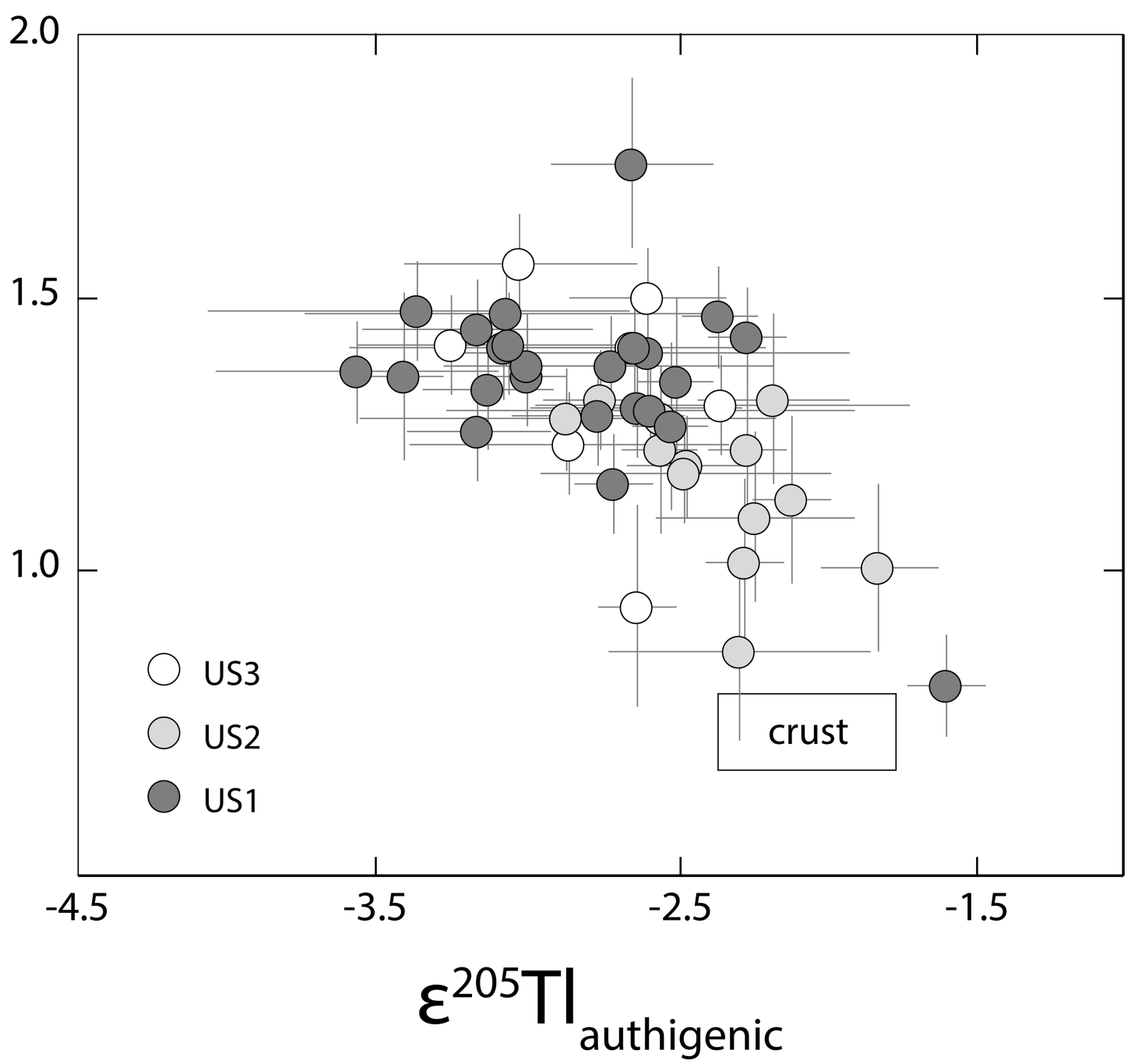

Figure 3. Mo and Tl isotope cross-plot from the upper shale member.

The anti-correlation trend in this plot, which is also apparent in Figure 1, is statistically significant ( $p$-value $=0.01$ ). The brown box indicates current estimates for the isotope compositions of bulk continental crust ${ }^{23,27}$. All error bars represent the 2SD reproducibility of that sample or the external long-term reproducibility of natural reference materials, whichever is greater. 
Table 1.

Standard solution $\delta^{98}$ Mo values from this study vs. previous work

\begin{tabular}{|c|c|c|c|c|}
\hline Standard & This study ${ }^{a}$ & $n$ & Normalized to NIST $+0.25 \%{ }^{b}$ & Goldberg et al. (2013) \\
\hline Roch-Mo2 & Bracketing std. & & $-0.09 \%$ & $-0.09 \pm 0.05 \% \circ$ \\
\hline ICL-Mo & $0.16 \pm 0.03 \% \circ$ & 38 & $0.07 \pm 0.03 \%$ & $0.09 \pm 0.05 \%$ \\
\hline Kyoto-Mo & $-0.04 \pm 0.05 \% \circ$ & 39 & $-0.13 \pm 0.05 \% \circ$ & $-0.12 \pm 0.06 \%$ \\
\hline NIST SRM 3134 & $0.33 \pm 0.06 \%$ & 45 & $0.24 \pm 0.06 \%$ & $0.25 \%$ (reporting std.) \\
\hline SDO-1 & $1.12 \pm 0.05 \%$ & 45 & $1.03 \pm 0.05 \% \circ$ & $1.05 \pm 0.14 \% \circ$ \\
\hline \multicolumn{5}{|c|}{ Measured relative to Roch-Mo2 } \\
\hline \multicolumn{5}{|c|}{ b. Normalized using $\delta^{98}$ Moroch-Mo2 $=-0.09 \%$ o relative to $\delta^{98}$ MoNIST $+0.25 \%$ o 56} \\
\hline
\end{tabular}

